\title{
The Sustainability of the Iron and Steel Industries in Ukraine: Challenges and Opportunities
}

\author{
Volodymyr Shatokha ${ }^{1}$
}

Published online: 10 December 2015

(C) The Minerals, Metals \& Materials Society (TMS) 2015

\begin{abstract}
The iron and steel industries are indispensable components of the Ukrainian economy: throughout the decades they have provided nearly $25 \%$ of GDP, $40 \%$ of export revenue, $25 \%$ of industrial production, and have employed over half a million people. Steelmaking is also the largest energy consumer of electricity and fossil fuels, being responsible for over $25 \%$ of hazardous atmospheric emissions and over $30 \%$ of carbon dioxide emissions from the country's industrial sources. The socio-economic, technological, and environmental aspects of sustainable industrial development have been studied based upon the data concerning mineral resources and fossil fuels, on the production facilities, on the steel consumption and export structures, etc. Current challenges, in relation to energy efficiency, the quality of raw materials, the conditions of equipment and technologies, the environmental impact, capacity utilisation, export dependency, and other factors have all been analysed. Opportunities to explore the potential of energy-saving and carbon-efficient technologies, as well as for enhancing domestic steel consumption, are presented.
\end{abstract}

Keywords Iron and steel industry - Sustainability · Carbon dioxide emissions · Energy efficiency

The contributing editor for this article was S. Kitamura.

Volodymyr Shatokha

shatokha@metal.nmetau.edu.ua

1 National Metallurgical Academy of Ukraine, Dnipropetrovsk, Ukraine

\section{Introduction}

The iron and steel industry has incredible importance for various components of Ukraine's sustainable development: it provides jobs to over half a million people, provides nearly $25 \%$ of GDP, $40 \%$ of export revenue, and $25 \%$ of industrial production. This industry is also responsible for over $25 \%$ of hazardous atmospheric emissions and over $30 \%$ of $\mathrm{CO}_{2}$ emissions from the industrial sources due to its largely obsolete facilities, being the largest energy consumer of electricity (15.6\%), and fossil fuels (14.2\%) [1]. Therefore, it is impossible for Ukraine to meet environmental sustainability standards and to ensure socioeconomic development without the radical modernisation of its iron and steel industry.

Steel production in Ukraine peaked at the level of 56.5 million tonnes per year in 1985 and then experienced several dramatic drops-following the collapse of the Soviet Union in the mid-1990s and the global recession in 2008. In 2014, steel output dropped by $17.1 \%$ year on year owing to political crises and military conflict, followed by the loss of governmental control over part of its industrialised eastern territories.

Ukraine's iron and steelmaking used to rely on its own abundant resources of iron ore and of coal, which is a very important economic factor, especially throughout the previous decade when prices for the raw materials fluctuated to a considerable degree. However, the economic sustainability of the industry has been greatly challenged by weak domestic demand for steel products; with less than $20 \%$ of its steel being consumed locally, Ukraine greatly depends upon the conditions of very competitive international steel markets.

Some remarkable modernisation projects have been undertaken recently; however, in general, the ferrous industry remains largely obsolete and energy-consuming. 
The technological sustainability of this industry in Ukraine will require essential revisions to the development strategy which aims at the rapid implementation of the best technologies available as well as in greater participation in international efforts of the commercialisation of innovative technologies.

\section{Natural Resources of Ferrous Metallurgy in Ukraine}

\section{Iron Ore}

With over $9 \mathrm{Gt}$ of probable reserve, Ukraine possesses the world's 3rd largest iron ore resource and the $4^{\text {th }}$ largest resource per capita [2]. In 1866, high grade iron ore was found near Kryvyi Rih which led to a boost in the mining and steelmaking industries in area ranging from Kryvyi Rih to Alchevsk (over $400 \mathrm{~km}$ from West to East), which is still the most important industrial region in Ukraine. Both openpit and shaft-mining are in place, with open-pits reaching $400 \mathrm{~m}$ in depth and shaft mines operating below $1200 \mathrm{~m}$. Currently, the recoverable reserve is estimated to exceed 30 billion tonnes, with the following distribution throughout the major geological basins [3]:

- 18.7 billion tonnes at the Kryvyi Rih basin;

- 4.5 billion tonnes at the Kremenchutskyi basin;

- 2.5 billion tonnes at the Bilozerskyi basin;

- 1.4 billion tonnes at the Kerch basin in Crimea (not exploited since 1992).

The operational reserve of iron ore, available for exploitation at various mining enterprises, is represented by the following types of iron ore:

- 1394.1 million tonnes of natural rich ore;

- 15,521.8 million tonnes of magnetite quartzite;

- 1027.8 million tonnes of oxidised magnetite quartzite.

In 2014, as much as 82.07 million tonnes of iron ore was produced in Ukraine (down $2 \%$ compared to 2013), coupled with the production of 67.9 million tonnes of iron ore concentrate (down $2.9 \%$ compared to 2013). Prior to the current crisis, Ukraine had been the world's 4th biggest exporter of iron ore. In 2013, as much as 37.98 million tonnes-almost half of the iron ore produced worldwide-was exported, mainly to China (46.3\%), the Czech Republic (12.2\%), and Poland (10.4\%). Pellets, as well as iron ore, were exported; in 2013, Ferrexpo (the Poltava mining and beneficiation company) alone exported over 10 million tonnes of iron ore pellets - to the EU, China, India, and Japan $[4,5]$.

Thanks to its geographic location, iron ore resources have not been directly affected by the current military conflict. However, due to the decreased domestic demand, iron ore production in Ukraine dropped by $5 \%$ during January-June 2015: the iron ore supply to domestic steel producers was down by $34 \%$, while export was up $18 \%$, year on year [6]. Revenues from iron ore export also shrank though, owing to the decreased iron ore prices on the global markets.

\section{Coal}

Ukraine possesses the largest coal deposit in Europe with over 55 billion tonnes of assured resource and 120 billion tonnes of probable reserves, $97 \%$ of which lie in the Donetsk coal basin. Just $12-15 \%$ of these resources are coking grade coals. Substantial parts of the available coal are deep-mined: most of the mines are 400-800 m deep, some operate at depths of 1000-1300 m. Aggregate annual production for all coal grades peaked in 1970 at the level of 177.8 million tonnes.

Coking coal production peaked in 1980 at the level of 88.4 million tonnes. In 2013, well before and irrespective of the crisis to come, just 24.1 million tonnes of coking grade coal was produced, the lowest yield in the last 20 years. This was followed by the importation of as much as 10.9 million tonnes of both coking grade and PCI (pulverised coal injection) grade coal in 2013. The reasons for importation were the high sulphur content in domestic coal (up to $3.5 \%$ of total Sulphur per dry mass) and the shortage of relevant coal grades. At the same time, 6.1 million tonnes of coal was exported in 2013, mostly anthracite [1].

Currently, the majority of mines, notably those producing coking grades and nearly a half of total coke production capacity (five out of twelve coke-making factories), lie in the territory out of governmental control. At least three cokemakers have become involved in a "hot conservation".

According to the data from Metallurgprom, the Association of Ukrainian steelmakers, the domestic coking coal supply has dropped by $56 \%$ during January-June 2015, year on year. The import of coking coals has decreased by $17 \%$ in the same period, while the share of imported coals in coking mix has jumped to $63 \%$ (47\% in 2014). Traditionally, most coking coal was imported from Russia; however, throughout January-June 2015 coking coal importation from Russia shrank by $41 \%$ [6]. For the year of 2015, Ukrkoks, the Association of Ukrainain cokemakers, envisages a further decrease of the domestic coal supply, coupled with the increased importation of coking coal to 12-14 million tonnes, as well as up to 2 million tonnes of coal for PCI [7].

In order to secure availability of coke for steelmakers, importation quotas have been lifted, resulting in the delivery 0.8 million tonnes of coke in January-June 2015 to Ukraine, an almost threefold rise year on year, with Poland being the major supplier [6]. 


\section{Ironmaking and Steelmaking}

\section{General Data}

From pre-recession 2007 through 2014, Ukraine's share in the world's crude steel production has shrank from 3.2 to $1.6 \%$. In 2013, Ukraine was the world's 3rd largest producer of steel per capita-after South Korea and Japan (Table 1, data by the WorldSteel [8]). In 2014, despite steel output dropping by $17.1 \%$, Ukraine retained its 10th place among the world's steel producers; however, in JanuaryJune 2015 crude steel production dropped by $27.2 \%$ year on year, seeing the county fall to 11 th position in the global rating and Italy became the 10th (semi-annual indicator).

The robust domestic demand for steel products is an important constituent of economic sustainability for the steel industry. However, domestic consumption of steel products in Ukraine used to be relatively weak with the share of finished steel consumed locally fluctuating around $20 \%$. In 2014, Ukraine's domestic consumption of steel was down by $38.9 \%$ year on year. Correspondingly, the share of steel consumed locally in 2014 was just $14.5 \%$ of the total amount of steel produced. Therefore, the industry's dependence upon exports increased drastically, challenging its economic sustainability. The structure of export and domestic consumption of finished steel products in Ukraine is shown in Table 2. In 2014, Ukraine's total export of steel products was down $12.6 \%$, year on year, while exports to the CIS countries were down $32.5 \%$ [6].

In 2013 , before the current crisis, Ukraine was the $4^{\text {th }}$ biggest steel exporter ( $3^{\text {rd }}$ by the net export indicator), as shown in Table 3 [8]. Export by product types is largely oriented to semi-products (over $45 \%$ ). The exports of finished steel is almost equally represented by flat (up to $30 \%$ ) and long (about $25 \%$ ) products. A more detailed structure of products exported in 2013 is shown in Fig. 1a. In 2014 , total exports declined by $16 \%$ for semi-finished, by $12 \%$ for long, and by $8 \%$ for flat steel products. During January-June 2015, this trend remained with the further decline by 31,20 , and $30 \%$ year on year, respectively [6].

The structure of exports by world regions in 2013 is demonstrated in Fig. 1b. According to data from the Ukrainian Industry Expertise state consultancy company [9], rolled steel exports were down to Russia by $27 \%$, to Middle East by $15 \%$, to EU Europe by $4 \%$, and to nonEU Europe by $10 \%$, whereas export to Africa grew by $15 \%$ and to the USA it had jumped by $50 \%$ in 2014 .

The ferrous industry in Ukraine has a very developed infrastructure, represented by the following types of enterprises:

- 9 integrated steelmaking enterprises (3 of which now lie in occupied territory, operation disrupted), plus a number of non-integrated producers of steel;

- 3 ferroalloys plants (1 of which now lies in the occupied territory, operation disrupted);

- 14 iron ore mining and beneficiation enterprises;

- 12 cokemaking factories (5 of which now lie in the occupied territory, operation disrupted);

Table 2 Structure of export and domestic consumption of finished steel products (ktonnes)

\begin{tabular}{llll}
\hline & 2013 & 2014 & $\%$ 2014/2013 \\
\hline Production of finished steel & 28,722 & 23,629 & -17.7 \\
Total export & 23,130 & 20,210 & -12.6 \\
To former soviet union & 4477 & 3023 & -32.5 \\
To the rest of the world & 18,653 & 17,187 & -7.9 \\
Domestic consumption & 5592 & 3419 & -38.9 \\
Long product & 3037 & 1685 & -44.5 \\
Flat product & 2370 & 1523 & -35.7 \\
Semi-product & 106 & 156 & +47.2 \\
Other & 79 & 55 & -30.4 \\
\hline
\end{tabular}

Table 1 List of the top ten steel producers

\begin{tabular}{llllll}
\hline No & Country & \multicolumn{3}{l}{ Production of crude steel } & \\
\cline { 3 - 6 } & & $\begin{array}{l}2014, \text { million } \\
\text { tonnes }\end{array}$ & $\begin{array}{l}\text { 2013, million } \\
\text { tonnes }\end{array}$ & $2014 / 2013, \%$ & kg per capita (2013) \\
\hline 1 & China & 822.7 & 815.4 & +0.9 & 571.2 \\
2 & Japan & 110.7 & 110.6 & +0.1 & 870.0 \\
3 & United States & 88.3 & 86.9 & +1.7 & 273.7 \\
4 & India & 83.2 & 81.3 & +2.3 & 65.3 \\
5 & South Korea & 71.0 & 66.1 & +7.5 & 475.3 \\
6 & Russia & 70.7 & 68.9 & +2.6 & 1314.2 \\
7 & Germany & 42.9 & 42.6 & +0.7 & 527.8 \\
8 & Turkey & 34.0 & 34.7 & -1.8 & 452.6 \\
9 & Brazil & 33.9 & 34.2 & -0.7 & 170.1 \\
10 & Ukraine & 27.2 & 32.8 & -17.1 & 722.3 \\
\hline
\end{tabular}


Table 3 List of the top steel exporters, million tonnes (data for 2013)

\begin{tabular}{|c|c|c|c|c|c|}
\hline \multicolumn{3}{|c|}{ Total export } & \multicolumn{3}{|c|}{ Net export } \\
\hline Rank & Country & $\begin{array}{l}\text { Million } \\
\text { tonnes }\end{array}$ & Rank & Country & $\begin{array}{l}\text { Million } \\
\text { tonnes }\end{array}$ \\
\hline 1 & China & 61.5 & 1 & China & 46.8 \\
\hline 2 & Japan & 42.5 & 2 & Japan & 37.1 \\
\hline 3 & South Korea & 28.9 & 3 & Ukraine & 23.0 \\
\hline 4 & Ukraine & 24.7 & 4 & Russia & 17.1 \\
\hline 5 & Germany & 24.3 & 5 & South Korea & 9.9 \\
\hline
\end{tabular}

a

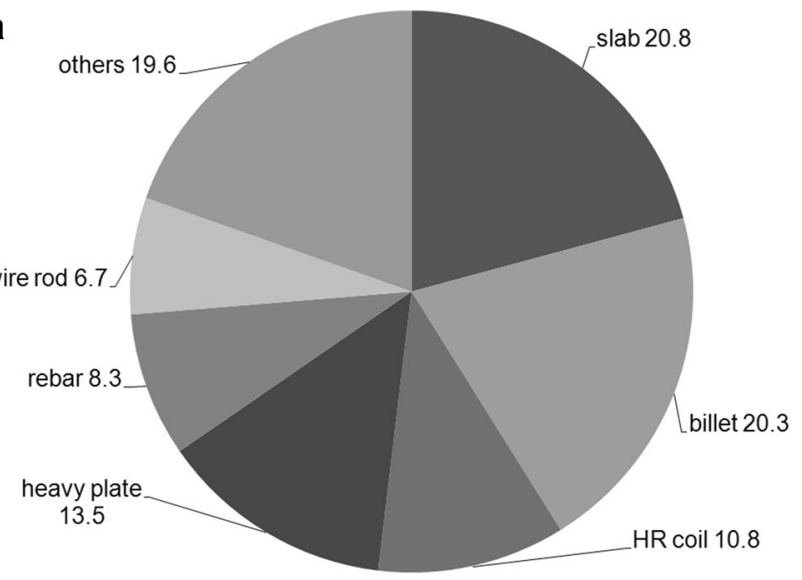

b

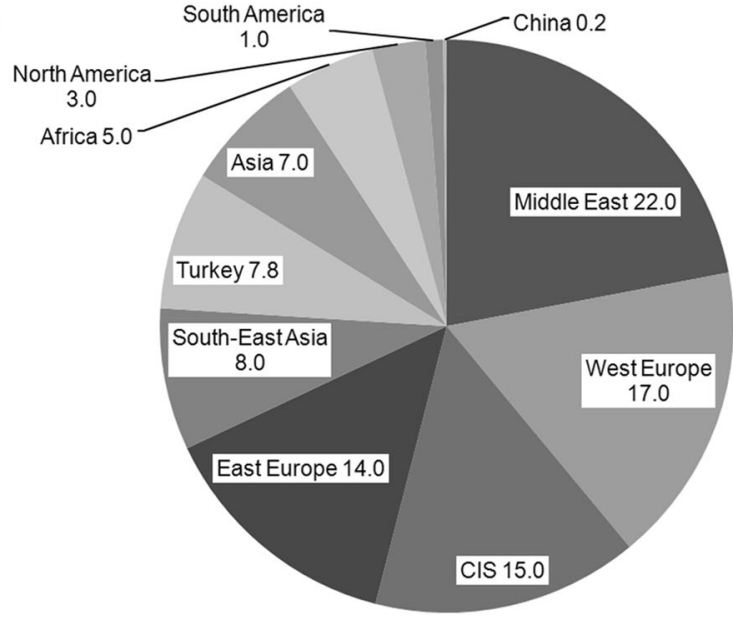

Fig. 1 Structure of Ukraine's steel export by product (a) and region (b) in 2013

- 13 refractory enterprises (many in the occupied territory, conditions unknown);

- 20 metalware enterprises (many in the occupied territory, conditions unknown);

- 8 large pipe rolling enterprises etc. (one of which lies in Khartsyzsk, a producer of pipes for long-distance pipelines, in the occupied territory and does not operates).

Production levels for major commodities by the iron and steel industries in 2013 and 2014 are represented in Fig. 2 [6].

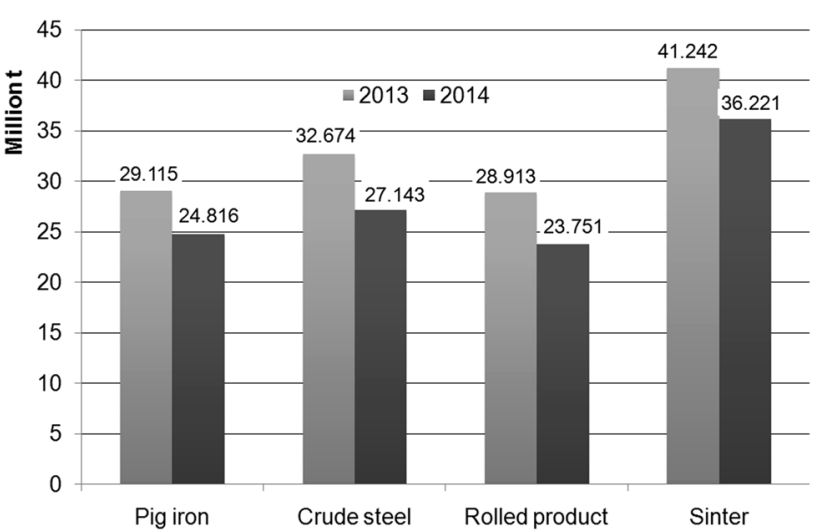

Fig. 2 Production of ferrous commodities in Ukraine

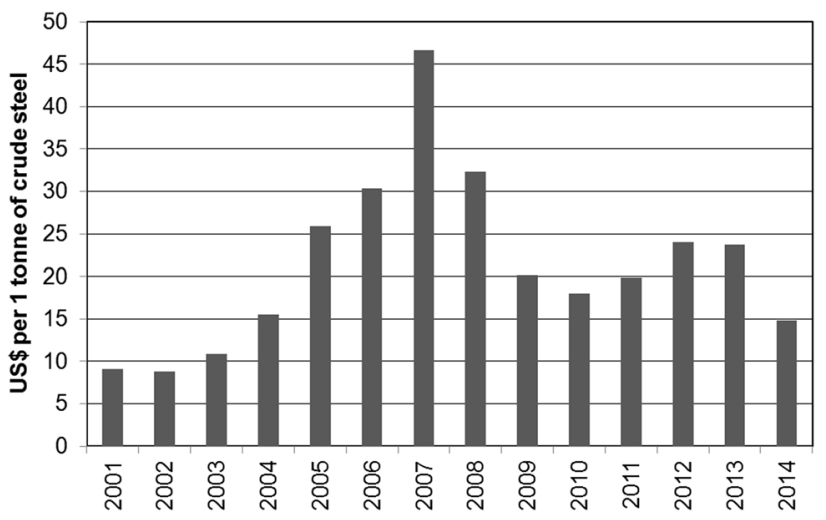

Fig. 3 Investments to fixed assets in iron and steel industry

During the 1990s, Ukraine's steel industry underwent periods of economic collapse, privatisation, global recession and political instability, meaning that levels of investments were insufficient and that posed a challenge to all aspects of sustainability-economic, technological, and environmental ones. The share of fixed assets with a $100 \%$ depreciation has reached extremely high levels (\%): Coke ovens-54, Blast furnaces-89, Open hearth furnaces-87, Basic oxygen furnaces-26, Rolling mills-90 [1]. Specific investments, incurred by steelmaking companies over the last several years, are demonstrated by Fig. 3. Investment levels were far from being sufficient to modernise the 
industry essentially, with respect to conditions of the equipment and technologies used, even during the flourishing pre-recession times. Following the financial crisis, when fuel costs were high and profit margins narrowed, investment levels declined: where in 2007 specific investments to the fixed assets reached the level of US $\$ 47.88$ per tonne of crude steel, in 2013 this indicator dropped to less than US\$ 23. During Q1-Q3 of 2014, investments fell to less than US $\$ 15$ per tonne of crude steel (estimation made based on Ukrainian Hryvna exchange rate as of September 1,2014 , later estimate are constrained by the instability of the Ukrainian currency) focusing mainly on finishing projects started previously [9].

\section{Ironmaking}

The production of hot metal in blast furnaces for the past 15 years is represented in Fig. 4a; after a dramatic $30 \%$ drop during 2007-2009, production recovered in 2011 by about $15 \%$, then stabilised at about 29 million tonnes per year; however, in 2014 it fell again by $15 \%$ to 24.81 million tonnes.
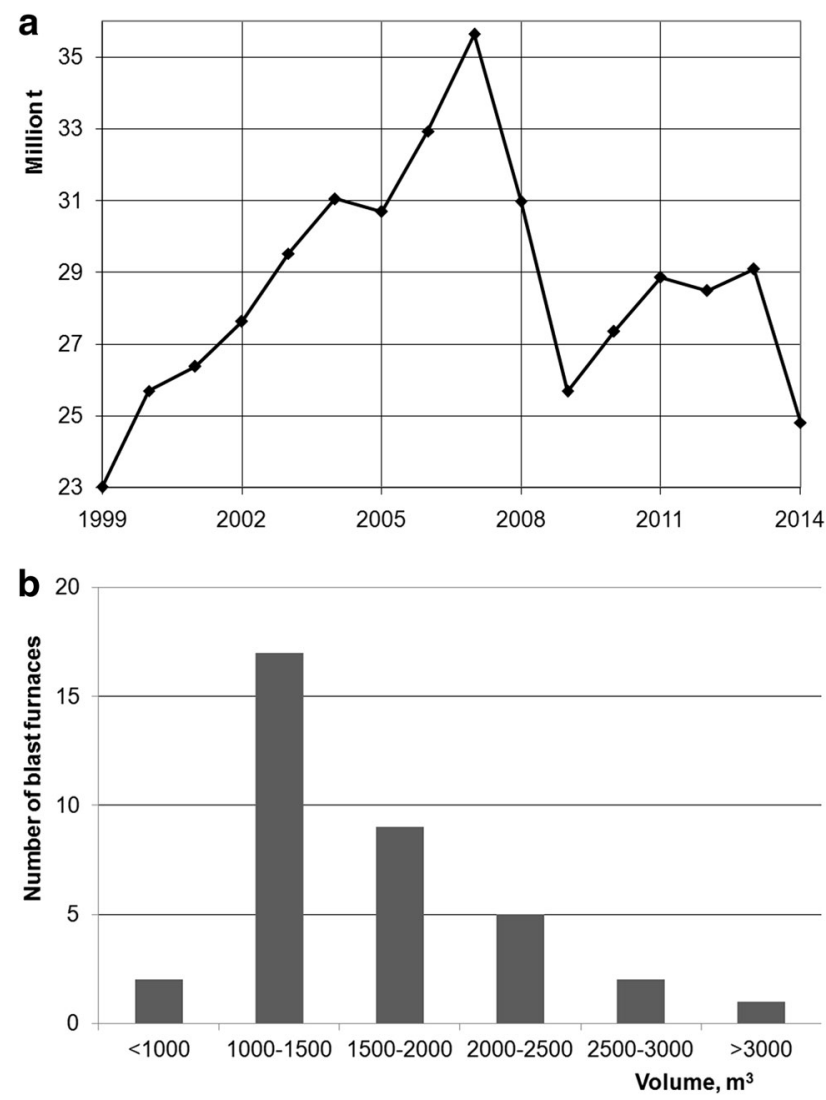

Fig. 4 Characteristics of Ukraine's ironmaking: a production and b distribution of furnaces by volume
The total number of blast furnaces capable of operation is reported as being 30 , though just 22 were reported as operating in July 2015. By March 2015, all blast furnaces in Alchevsk, Donetsk, and Yenakieve were stopped for an undefined term [6].

The distribution of the blast furnaces available by a useful volume (between the taphole and the throat levels) is shown in Fig. 4b. Most furnaces are relatively smallranging from 1000 to $2000 \mathrm{~m}^{3}$. The largest blast furnace has a volume of $5035 \mathrm{~m}^{3}$ (ArcelorMittal Kryvyi Rih) and was erected in 1974.

Although Ukraine was a pioneer in implementing the PCI technology with the industrial injection of pulverised coal, that begun as early as 1967, up until 2010 only one enterprise, Donetsksteel, had used this technology, while the injection of natural gas has been the most common method employed to reduce coke consumption. Following the rise of natural gas prices, in 2013 the PCI technology was implemented at another three (Alchevsk, Ilyich and Zaporizhstal integrated steelworks) and at one more enterprise (Dniprovsky Iron \& Steel Works) in 2014. The efficiency of PCI technology is challenged by the need to enhance coke quality, which requires increased import of high grade coking coal and/or coke. Other challenges, such as high sulphur and ash contents of the domestic coals used for PCI, should also be noted.

\section{Steelmaking}

The evolution of crude steel production in Ukraine over the last century is presented in Fig. 5. Like ironmaking, steelmaking also, after a $30 \%$ drop during 2007-2009, recovered in 2011 by $15 \%$, thus demonstrating the fragile competitiveness of Ukraine's steel sector on the global market. Capacity utilisation, even prior to the political crisis, was rather low, though real figures are difficult to estimate owing to the uncertainty of the data concerning the conditions of the equipment available at some enterprises, especially for the

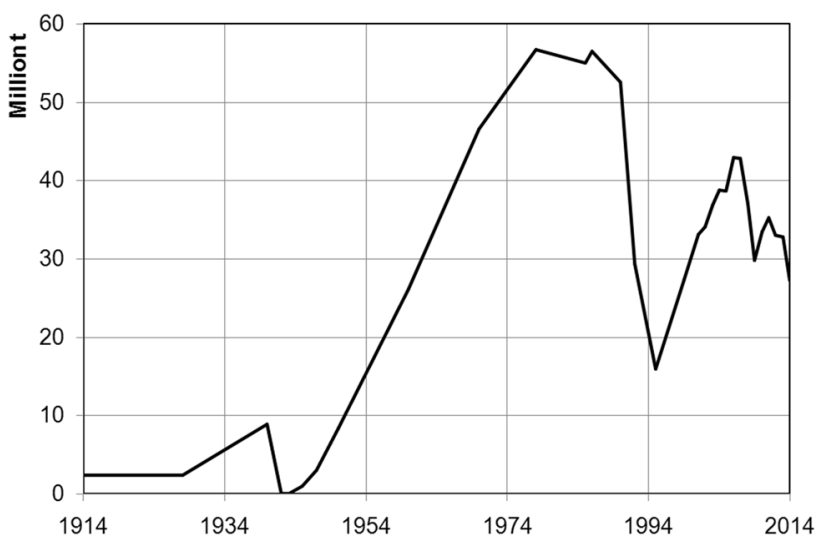

Fig. 5 Evolution of steel production in Ukraine over the century 
non-integrated ones. With 32.8 million tonnes being produced in 2013, a capacity utilisation level of $74.9 \%$ was officially reported by Metallurgprom [6]. In 2014, the average capacity utilisation declined to less than $50 \%$, though this figure actually combines data for the enterprises operating and those staying idle. Data concerning the production of crude steel by integrated steelmakers are shown in Table 4, and by non-integrated companies in Table 5 (list does not include some minor steel producers).

From 2008 to 2013, steel production capacity decreased from 47.8 million tonnes to 43.8 million tonnes, mainly due to the elimination of obsolete open hearth furnaces (OHF) at Azovstal, Donetsksteel, Interpipe, and some other enterprises. The structure of steel production changed drastically; for a very long period the share of the OHFs in steel production was well above $50 \%$, while in 2013 it dropped to less than $20 \%$ (Fig. 6a). The most remarkable event was the elimination of OHFs and the launch of the new steelmaking enterprise by Interpipe (non-integrated, seamless pipes, and railway wheels producer) which had an annual capacity of 1.32 million tonnes in October 2012, the largest investment project in Eastern Europe and the first green-field project in Ukraine in the past 50 years, comprising a total of US\$700 million. This enterprise is equipped with 186 tonnes EAF, ladle-furnace, vacuum degassing, vacuum oxygen decarburisation, and two continuous casting machines to produce round billet (between 150 and $450 \mathrm{~mm}$ in diameter).
Another investment project that sought to substitute OHFs with EAF production capacity of 1.4 million tonnes at Donetsksteel, was demolished and cleared in 2012, was postponed many times and, being very close to completion in 2014, was not finalised due to the current situation in Ukraine. Other investment projects-announced before the current crisis-envisaged the elimination of OHFs with a production capacity of about 10 million tonnes at ArcelorMittal Kryvyi Rih, Ilyich Iron and Steel Works, Zaporizhstal Iron \& Steel Works in order to produce all the steel through the BOF method at these enterprises by 2017.

Statistics on the number of the various kinds of furnaces (BOF-basic oxygen furnace, OHF-open-hearth furnace, EAF-electric arc furnace) available at the enterprises, as reported by Metallurgprom in January 2014, is shown in Table 6. In 2010, figures for the OHFs were reported by Metallurgprom as being: 35 available and 31 in operation [10]. In the same report, the closure of 19 OHFs, with the total annual capacity of 8.1 million tonnes by the year 2015, was also announced. Therefore, results achieved by 2014 (Table 3) are generally consistent with the strategic targets set 5 years ago for 2015 .

The share of continuously cast steel in Ukraine remains relatively low (Fig. 6b), even though several investment projects have been announced and some were even completed before the political crisis. In particular, at ArcelorMittal Kryvyi Rih, the continuous casting department was launched in August 2011, to fulfil the obligations

Table 4 Production of crude steel by the integrated companies

\begin{tabular}{|c|c|c|c|c|}
\hline Enterprise & $\begin{array}{l}\text { Owner or major } \\
\text { shareholder }\end{array}$ & $\begin{array}{l}\text { Production in } \\
2013 \text { (million } \\
\text { tonnes) }\end{array}$ & $\begin{array}{l}\text { Production in } \\
2014 \text { (million } \\
\text { tonnes) }\end{array}$ & Remarks \\
\hline $\begin{array}{l}\text { ArcelorMittal } \\
\text { Kryvyi Rih }\end{array}$ & ArcelorMittal & 7.44 & 6.30 & \\
\hline $\begin{array}{l}\text { Alchevsk Iron \& } \\
\text { Steel Works }{ }^{\mathrm{a}}\end{array}$ & ISD & 4.17 & 2.50 & Operation stopped since Aug 2014 \\
\hline $\begin{array}{l}\text { Azovstal Iron \& } \\
\text { Steel Works }\end{array}$ & Metinvest & 4.47 & 3.60 & $\begin{array}{l}\text { Operation challenged by logistical problems and damaged } \\
\text { infrastructure (railway, gas and water pipelines) }\end{array}$ \\
\hline $\begin{array}{l}\text { Ilyich Iron \& Steel } \\
\text { Works }\end{array}$ & Metinvest & 5.03 & 3.50 & \\
\hline $\begin{array}{l}\text { Zaporizhstal Iron \& } \\
\text { Steel Works }\end{array}$ & Metinvest & 3.82 & 3.96 & \\
\hline $\begin{array}{l}\text { Dniprovsky Iron } \\
\text { \& Steel }\end{array}$ & ISD & 2.93 & 2,53 & \\
\hline $\begin{array}{l}\text { Yenakiieve Iron \& } \\
\text { Steel Works }\end{array}$ & Metinvest & 2.89 & 2.10 & Operation stopped in Sep 2014, resumed early Mar 2015 \\
\hline $\begin{array}{l}\text { EVRAZ DMZ } \\
\text { Petrovskogo }\end{array}$ & EVRAZ & 0.996 & 0.986 & \\
\hline $\begin{array}{l}\text { Donetsksteel Iron } \\
\& \text { Steel Works }\end{array}$ & Donetsksteel & $0^{\mathrm{b}}$ & 0 & Operation stopped early Feb 2015 \\
\hline
\end{tabular}


Table 5 Production of crude steel by non-integrated companies (all-EAF)

\begin{tabular}{|c|c|c|c|c|}
\hline Enterprise & $\begin{array}{l}\text { Owner or major } \\
\text { shareholder }\end{array}$ & $\begin{array}{l}\text { Production in } 2013 \\
\text { (million tonnes) }\end{array}$ & $\begin{array}{l}\text { Production in } 2014 \\
\text { (million tonnes) }\end{array}$ & Remarks \\
\hline Donetsk electrometallurgical plant ${ }^{a}$ & Mechel & 0.505 & No data & Operation stopped \\
\hline Electrostal DMPZ $^{\mathrm{a}}$ & Electrostal & 0.475 & No data & Operation stopped \\
\hline Energomashspetstal & Atomenergomash & 0.108 & No data & \\
\hline Dneprospetstal & ING Group & 0.275 & 0.278 & \\
\hline Interpipe-steel & Interpipe Group & 1.028 & 0.888 & \\
\hline
\end{tabular}

${ }^{a}$ In occupied territory
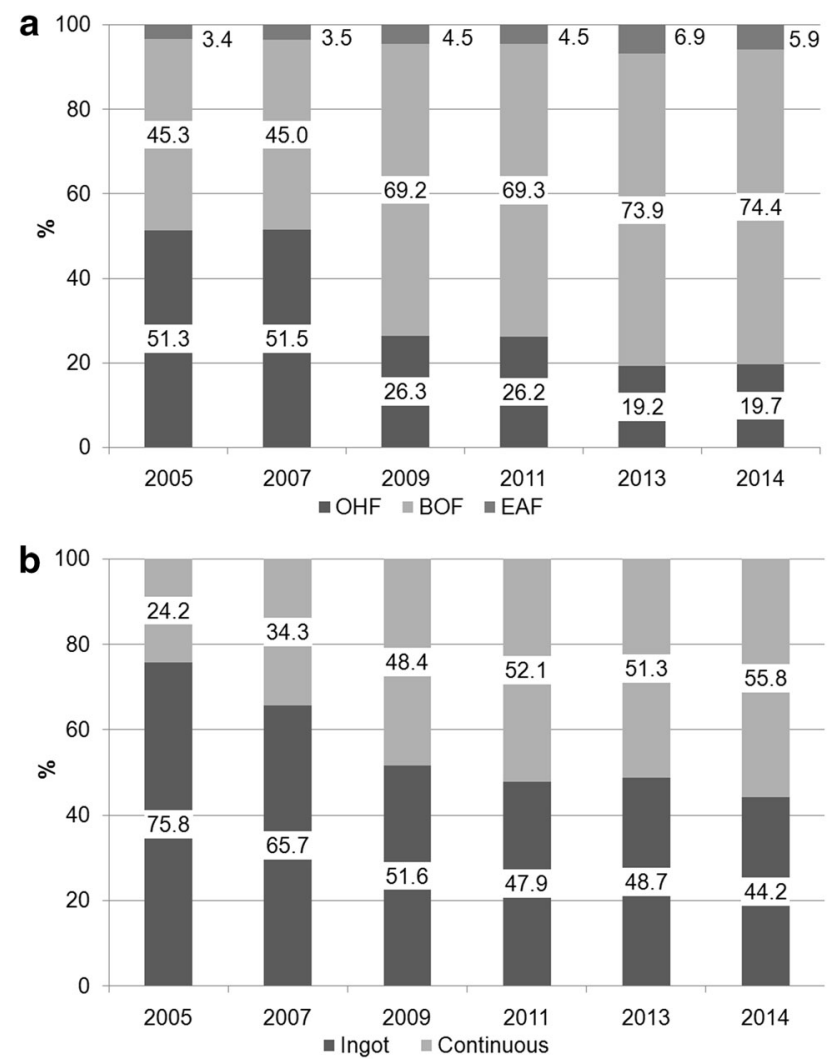

Fig. 6 Structure of steel production by: a steelmaking method; b casting method

Table 6 Types and number of steelmaking furnaces available

\begin{tabular}{llll}
\hline Status & BOF & OHF & EAF \\
\hline Available & 21 & 14 & 15 \\
In operation & 17 & 8 & 4 \\
\hline
\end{tabular}

undertaken as part of a sales and purchase agreement signed in October 2005. The project required a total investment of US\$ 120 million. A designed capacity of 100 kt per month was reached in January 2013. Today, the continuous casting department operates a ladle furnace and six radial-type strand billet casters, producing billets from carbon, structural, and low-alloyed steel grades. The construction of a second continuous casting machine was also announced [11]. Plans, revealed by Metallurgprom before the crisis, envisaged $79.1 \%$ target for continuously cast steel to be achieved by 2015; however, under current conditions, the feasibility of this target is unclear.

\section{Energy Efficiency and Environmental Footprint}

Figure 7 demonstrates the energy saving potential for the steel industries for some countries to be achieved through the implementation of the best technologies available (data by International Energy Agency [12]). Ukraine has the highest specific figure and, therefore, its greatest achievable energy saving potential value is nearly equal to those of Japan, South Korea, and Canada put together. This major effect might be achieved by the further substitution of the OHF by BOF and improvements to the blast furnace's operation. The energy saving potential is proportional to a carbon dioxide reduction value given that over $95 \%$ of $\mathrm{CO}_{2}$ emissions in iron and steel industry originate from fossil fuels.

Data concerning the atmospheric emissions from Ukraine's iron and steel industries are shown in Table 7 $[13,14]$. Shares of different sectors in atmospheric pollution by the steel industry are demonstrated in Fig. 8. Sintering is the major source of both types of atmospheric emissions-solid and gaseous ones. Figures for air pollution specifically tend to decrease-mainly owing to the substitution of OHF by BOF in steelmaking. Lower air pollution in 2014 is the result of decreased production and the non-accounting of those enterprises on the occupied territory. Carbon dioxide emissions ${ }^{1}$ increased since 2011, which is mainly caused by the natural gas consumption reduction from 9.5 billion $\mathrm{m}^{3}$ in 2007 to 2.5 billion $\mathrm{m}^{3}$ in

\footnotetext{
${ }^{1}$ Data by the Ukrainian state statistics committee, methodology and boundaries are not disclosed; figures look generally underestimated, taking into account the high energy consumption per tonne of steel produced.
} 

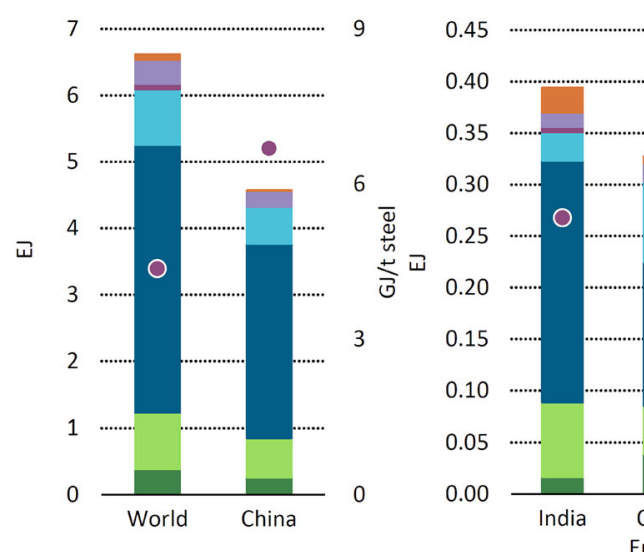

Savings potential (GJ/t steel)

Reduced electricity use from continuous casting

Increased efficiency of power generation from blast furnace gas Switch from OHF to BOF

Increased BOF gas recovery

Blast furnace improvements

Coke oven gas recovery

Coke dry quenching or advanced wet quenching

Fig. 7 Energy savings potential for the world's major steel producers

Table 7 Emissions to the atmosphere from iron and steel industry

\begin{tabular}{|c|c|c|c|c|c|c|c|c|}
\hline & 2007 & 2008 & 2009 & 2010 & 2011 & 2012 & 2013 & $2014^{\mathrm{a}}$ \\
\hline Air pollution by iron \& steelmaking (kilotonnes) & 1397.2 & 1149.7 & 926.7 & 1076.8 & 1102.3 & 1015.8 & 1004.6 & 802.1 \\
\hline $\begin{array}{l}\text { Share of iron \& steelmaking in total air pollution by all } \\
\text { economic activities }(\%)\end{array}$ & 29.0 & 25.4 & 23.6 & 26.1 & 25.2 & 23.4 & 23.4 & 26.4 \\
\hline Air pollution per 1 tonne of steel $(\mathrm{kg})$ & 32.6 & 31.0 & 31.1 & 32.2 & 31.2 & 30.4 & 30.6 & 29.4 \\
\hline $\mathrm{CO}_{2}$ emission from iron \& steelmaking (kilotonnes) & n.a. & $38,207.2$ & $34,348.3$ & $39,234.8$ & $64,073.1$ & $59,188.1$ & $60,520.6$ & n.a. \\
\hline $\begin{array}{l}\text { Share of iron \& steelmaking in total amount of } \mathrm{CO}_{2} \text { emissions } \\
\text { from all economic activities }(\%)\end{array}$ & n.a. & 21.9 & 22.5 & 23.8 & 31.7 & 29.9 & 30.6 & n.a \\
\hline $\mathrm{CO}_{2}$ emissions per 1 tonne of steel (tonnes) & n.a. & 1.0 & 1.1 & 1.2 & 1.8 & 1.8 & 1.8 & n.a \\
\hline
\end{tabular}

${ }^{a}$ Data do not include enterprises on the occupied territories

2014; the substitution of natural gas in ironmaking with PCI has resulted in the essential growth of carbon dioxide emissions.

\section{Vision for the Sustainable Future of Ukraine's Steel Industry}

It is very difficult to develop credible scenarios for the steel industry in Ukraine, owing to the complexity of its economic and political conditions at present. However, an analysis of existing challenges and opportunities helps to formulate some aspects in the context of sustainable development.

1. Situations regarding the depreciation of fixed assets in other industrial sectors and fields of economic activities in Ukraine are quite similar to those in steel industry. Therefore, the accumulated demand for replacing depreciated steel-made facilities is estimated to be 330 million tonnes of steel, to be produced and consumed on the domestic market for the purposes of reconstruction in sectors such as housing and municipal economy, transport infrastructure, industrial structures and buildings, tubes and pipelines, etc. [13]—the value close to 10 years of steel production output, with a nearly full utilisation of current capacity. In the case that the conflict in eastern Ukraine, where the industrial and civil infrastructures have been severely damaged by the military action, were to be peacefully resolved, this figure would be even higher. The lasting domestic demand for steel is an important factor in future economic sustainability for industry in Ukraine, 

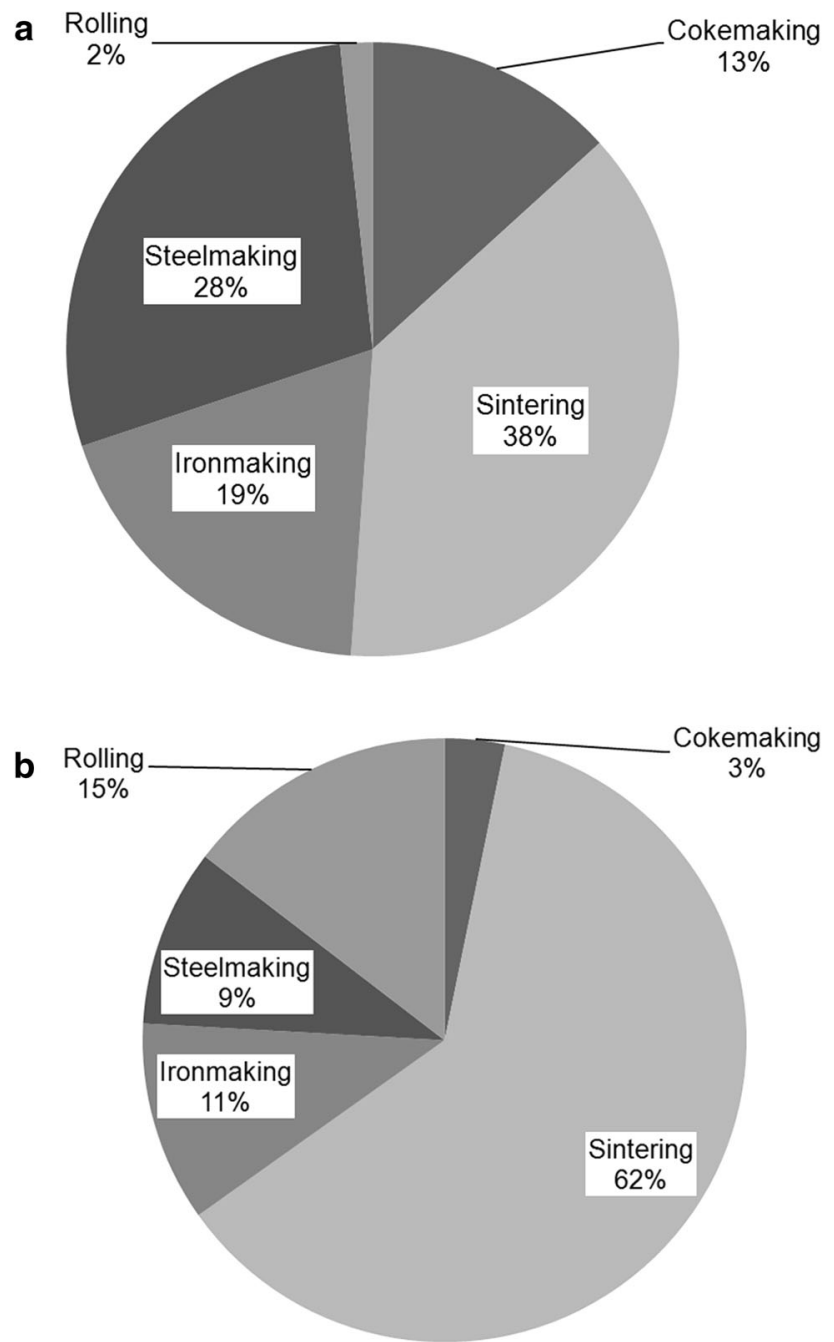

Fig. 8 Distribution of solid (a) and gaseous (b) atmospheric emissions among the major steel industry sectors

thereby making it less export-dependent. This is also linked to social sustainability with respect to the number of people working for the steel industry and related sectors of the economy. Scrap availability, in this scenario, reducing the need for primary steel (produced from pig iron) and this might result in decreased specific carbon dioxide emissions, thus greatly contributing to industry's environmental sustainability.

2. Most of the coal mines and an essential number of the cokemaking factories are on the territories that are currently beyond the government's control. Therefore, at least in the short term, steelmakers have to look for other, more reliable sources of solid fuel. However, even if the territories were to be brought back under governmental control, conditions at some of the mines may hamper their exploitation, owing to the damage incurred. This may change the pattern of the iron and steel industries drastically with respect to the facts that (i) coal mining in Ukraine was, to a great extent, economically unfeasible (many mines were supported by the government for social reasons) and (ii) that coal is an abundant resource worldwide. In particular, blast furnace operation was traditionally oriented to operate under conditions in which high sulphurous coke was used in a feed, keeping the slag basicity elevated $\left(1,15-1,25 \mathrm{CaO} / \mathrm{SiO}_{2}\right)$ with the purpose of producing iron with ca. $0,03 \%$ of sulphur. In combination with the use in the blast furnace feed of an iron ore with relatively low iron content and of a limestone, this was followed by extremely high slag yield (up to $480 \mathrm{~kg}$ per tonne of hot metal) and, consequently, by high coke consumption in ironmaking-both factors which affect energy efficiency and environmental footprint. In the past, a trade-off between the use of low quality domestic solid fuel against the importation of better (and sometimes even cheaper) ones was always balanced in favour of the former, mostly owing to the social and infrastructural and/or logistical factors. However, under the current conditions this attitude may change. If this is to be the case, coke specific consumption in ironmaking may drop and carbon dioxide emissions, as well as emissions of hazardous sulphur oxides, will decrease, thereby enhancing the environmental sustainability of the industry.

3. The trade with Russia has shrunk drastically already, even though essential part of industry is owned by some Russian companies such as EVRAZ, Mechel, Atomenergomash or companies in which Russian capital is the major shareholder, such as ISD (see also Tables 4 and 5). There is a need not only to look for new markets for the steel industry but also to restructure and to modernise the heavy manufacturing industries towards the needs of markets other than CIS one, taking into account that Russia has also ceased to be a major importer of Ukraine's metal-intensive products, such as e.g. railway cars. Even though it constitutes a challenge at present, in the future-if the problem is addressed adequately through the technological advancements required to meet the demands of the developed markets - this might lead to the creation of a more robust and advanced industrial infrastructure.

4. Ukraine has the huge potential to reduce its energy consumption and, parenthetically, to cut its carbon dioxide emissions. From the point of view of savings, it is possible to judge that these reductions can be achieved much easier and at a lower cost than in the majority of other countries. If the pledges to cut GHG emissions recently announced by governments worldwide will come into force under the Kyoto Protocol's 
successor and some flexibility mechanisms (such as Clean Development Mechanism, International Emissions Trading and Joint Implementation) are introduced, there will be plenty of "low hanging fruits" to harvest in terms of GHG emissions reduction, which will make Ukraine attractive to investors. Moreover, with its need to modernise and/or substitute technologies and equipment, Ukraine can be a testing-ground not only for the implementation of the best technologies available, but also by providing a "brown field" for the commercialisation of some radically innovative technologies including those being developed by industrialised countries such as e.g. HIsarna [15]. In addition to the considerations mentioned above (3), this creates the opportunity to enhance both components of technological and environmental sustainability.

\section{Conclusions}

Ukraine's iron and steel industries have survived through hard times, when the inherent challenges of technological obsolesce, the insufficient quality of raw materials, and poor domestic consumption were superimposed by the political crisis and military conflict. The latest trends point to the decline of steel production and the domestic demand for steel, to logistical problems and to the disruption of traditional patterns for the importing of raw materials and the exporting of steel products. At this point, the industry needs to revise the development strategy that aims at socioeconomical, technological, and environmental sustainability. The urgent need to replace existing technologies and equipment creates an opportunity to modernise the industry towards the best possible standards. Under conditions of carbon-constrained economy Ukraine has the potential to be attractive to investors, owing to the relatively low cost for cutting the carbon dioxide emissions, compared to other developed countries.

\section{References}

1. Shatokha V (2014) Iron and steel industry in Ukraine: current state, challenges and future perspective. In: Kongoli F (ed) Sustainable industrial processing summit/Schechtman International Symposium. Vol. 3: Non Ferrous, Iron and Steel. p 335-345

2. Muller DB, Wang T, Duval B (2011) Patterns of iron use in societal evolution. Environ Sci Technol 45:182-188

3. Kolosov V (2011) Development for mining industry. Quality of mineral resources. Kryvyi Rih Technical University, Kryvyi Rih, pp 35-42

4. https://www.steelfirst.com/Article/3435056/INTERVIEW-Lackof-profit-unlikely-to-deter-Ukraine-steel-exports-UEX-says.html. Accessed 19 August 2015

5. www.steelfirst.com/Article/3442017/Ferrexpo-reports-25-pelletoutput-rise-in-Q1-2015. Accessed 19 August 2015

6. http://metallurgprom.org. Accessed 19 August 2015

7. http://www.ukrrudprom.ua/news/Ukraina_sokratila_vipusk_koksa_ na_40_v_yanvare.html. Accessed 19 August 2015

8. www.worldsteel.org Accessed 19 August 2015

9. http://www.steelfirst.com/Article/3428053/Ukraine-rolled-steelexports-down-13-in-2014-on-disrupted-output.html. Accessed 19 August 2015

10. Kharakhulakh V (2010) Current state and perspectives for steelmaking in Ukraine. Metal and foundry in Ukraine 8:5-9

11. http://corporate.arcelormittal.com/news-and-media/news/2013/aug/ 22-08-2013. Accessed 19 August 2015

12. Energy technology perspectives: harnessing electricity's potential (2014) OECD/IEA

13. Amosha AI, Bolshakov VI, Minayev A et al (2013) Ukrainian metallurgy: current challenges and perspectives development, National Academy of Science of Ukraine. Institute of industrial economics, Donetsk

14. www.ukrstat.gov.ua. Accessed 19 August 2015

15. http://www.ulcos.org/en/research/isarna.php. Accessed 19 August 2015 